\title{
Resistance to Bacterial Spot in Bell Pepper Induced by Acibenzolar-S-Methyl
}

\author{
A. M. Romero, C. S. Kousik, and D. F. Ritchie, Department of Plant Pathology, North Carolina State University, \\ Raleigh 27695-7616
}

\begin{abstract}
Romero, A. M., Kousik, C. S., and Ritchie, D. F. 2001. Resistance to bacterial spot in bell pepper induced by acibenzolar-S-methyl. Plant Dis. 85:189-194.

Bell pepper plants sprayed with the chemical acibenzolar-S-methyl (ABM, Actigard $50 \mathrm{WG)}$ showed resistance to subsequent infections with the bacterial spot agent Xanthomonas axonopodis pv. vesicatoria. Induction of resistance was independent of the cultivar used, and was expressed as early as 3 days after treatment and continued for at least 2 weeks. In the field, applications of ABM every 2 weeks, alone or in combination with copper, resulted in disease control similar to the standard treatment of copper plus maneb. Yield response was variable, with certain combinations of chemical treatments and cultivars producing yields as large as the copper plus maneb treatment. In contrast, weekly applications during the entire crop season had a negative impact on yield. In plots maintained free of bacterial spot, applications of ABM every 2 weeks caused a reduction in yield for one cultivar of six tested. The use of chemical inducers for the control of bacterial spot on bell pepper, while generally promising, may result in an unpredictable loss in fruit yield.
\end{abstract}

Bacterial spot of bell peppers (Capsicum annuит L.) is especially damaging under warm, moist conditions (27). Management strategies for this disease include the use of presumed disease-free seeds and transplants, resistant cultivars, and chemical sprays. Results of chemical applications are often less than desirable because of the widespread occurrence of copper- and streptomycin-resistant strains of Xanthomonas axonopodis pv. vesicatoria $(14,21,30)$. Known plant resistance in this pathosystem is determined by gene-forgene interactions between race-specific host resistance genes and pathogen avirulence genes (16). Based on hypersensitive reactions on 'Early Calwonder' (ECW) and three near-isogenic lines, each with a single dominant resistance gene, seven pepper races have been described. Another resistance gene was found in C. pubescens (25), allowing the differentiation of four additional races $(22,25)$. Although there are many commercial hybrids with resistance to one or more races of $X$. axonopodis pv.

Corresponding author D. F. Ritchie

E-mail: david_ritchie@ncsu.edu

This research was supported in part by an NRI Competitive Grants Program/USDA Agreement No. 96-35313-3621 and by the North Carolina Agricultural Service (NCARS).

The use of trade names in this publication does not imply endorsement by the North Carolina Agricultural Research Service of the products named nor criticism of similar ones not mentioned.

Accepted for publication 25 October 2000.

Publication no. D-2000-1208-01R

(C) 2001 The American Phytopathological Society vesicatoria, race shifts in the field can defeat these genes in both experimental plots (9) and commercial fields, as occurred in Florida recently (19).

Plant activators may induce systemic resistance in plants. The first descriptions of induced resistance date to 1901 , when it was observed that plants previously infected by a pathogen became resistant to further infections (20). In 1961, Ross (24) coined the term systemic acquired resistance (SAR) to describe the long-lasting, broad-spectrum, systemic resistance to subsequent infections induced by a pathogen. Chemicals such as salicylic acid and 2,6-dichloro-isonicotinic acid (INA; 15,33) can also induce SAR. However, these chemicals can be phytotoxic to most crops and thus have not been exploited commercially. The compound acibenzolar-Smethyl (ABM), a benzothiadiazole (BTH), does not have this disadvantage. It has been released in Europe as BION (Syngenta Ltd., Basel, Switzerland) and in the United States as Actigard (Syngenta Crop Protection Inc., Greensboro, North Carolina). ABM has been reported to induce resistance in wheat against fungal pathogens $(6,17)$, in bean against bacterial and fungal infections (26), and in tobacco and Arabidopsis spp. against fungal, bacterial, and viral infections $(4,5,12)$. ABM complies with the definition of a SAR inducer: it gives protection to the same spectrum of pathogens, causes the expression of the same molecular and biochemical markers (e.g., pathogenesisrelated proteins) as biological inducers, and does not have direct antimicrobial activity (8). Resistance inducers are not necessarily a replacement for traditional fungicides and bactericides. Its use in conjunction with or alternated with these pesticides may lead to a reduction of the number of applications and perhaps dose rate $(13,18)$. It might also help extend the durability of resistance in cultivars with genes for resistance to specific pathogen races (23). Additionally, during SAR expression, several mechanisms appear to be activated simultaneously against the pathogen attack; therefore, the risk of development of SAR-insensitive strains seems very low (32).

Our main objective was to determine the potential for bacterial spot control on bell pepper with $\mathrm{ABM}$ and the duration of its protective effect. In the field, our objectives were to determine the effect of prolonged SAR induction on control of bacterial spot, crop yield, and yield components, and the possible use of ABM in combination with other pesticides for the control of bacterial spot.

\section{MATERIALS AND METHODS}

Bacterial strains. Strains of the pathogen that causes bacterial spot of pepper and tomato (Lycopersicum esculentum Mill.) are composed of two genetic groups (28). Vauterin et al. (34) placed the groups into two separate species, $X$. axonopodis pv. vesicatoria (A group, which is variably amylolytic) and $X$. vesicatoria (B group, which is strongly amylolytic). Strains used in the experiments reported here belong to the A group. Bacteria were stored in $20 \%$ glycerol at $-80^{\circ} \mathrm{C}$ and grown on modified yeast dextrose calcium carbonate (YDC) or modified sucrose peptone agar (SPA) (21) for 2 days at $28^{\circ} \mathrm{C}$ before use in inoculation.

Greenhouse experiments. Five cultivars of pepper were used, three with no known resistance genes (cvs. ECW, Camelot, and Jupiter) and two with one major gene for resistance each (cvs. ECW10R and X3R Camelot) (Table 1). Plants with two fully expanded true leaves were sprayed using a hand-pump bottle until runoff with a suspension of $\mathrm{ABM}$ (Actigard $50 \mathrm{WG}$ ) at $25 \mathrm{mg}$ a.i./liter. Challenge inoculations were done with $X$. axonopodis pv. vesicatoria Xcv 181 (race 4). All cultivars tested were susceptible to strain Xcv 181 (Table 1). Inoculations were done by immersing the plants for $20 \mathrm{~s}$ in an inoculum suspension (approximately $10^{5}$ CFU/ml) with $0.04 \%$ Silwet L-77 (10). The plants were kept in plastic bags for 3 days; after removal of bags, plants remained in the greenhouse. Challenges were done four times (at 3, 15, 30, and 40 days) 
after treatment. The experiment was conducted twice.

Disease was evaluated every 3 to 4 days using a 0 -to- 9 rating scale $(10)$, where $0=$ no diseased leaves; $1=<10 \%$ leaf area diseased; $5=41$ to $50 \%$ leaf area diseased or defoliated; $9=$ complete defoliation, plant dying or dead. The area under disease progress curves (AUDPC) was calculated as previously described (3).
Field experiments. Field experiments were conducted at the Sandhills Research Station, Jackson Springs, NC from 1996 through 1999. Plants were grown from seeds in a greenhouse for 7 to 8 weeks in polystyrene trays with $128 \quad 3.5-\mathrm{cm}$ cells and were transplanted during the last week of April or first week of May each year. Overhead irrigation was applied to the crop as needed to maintain optimum plant

Table 1. Pepper cultivars and races of Xanthomonas axonopodis pv. vesicatoria used in greenhouse and field experiments and their host phenotypic reactions

\begin{tabular}{lcccc}
\hline Cultivars $^{\mathbf{z}}$ & $\begin{array}{c}\text { Race 1 } \\
(\text { avrBs2, avrBs3) }\end{array}$ & $\begin{array}{c}\text { Race 3 } \\
(\text { avrBs2) }\end{array}$ & $\begin{array}{c}\text { Race 4 } \\
\text { (avrBs3) }\end{array}$ & $\begin{array}{c}\text { Race 6 } \\
\text { (none) }\end{array}$ \\
\hline Camelot & $\mathrm{C}$ & $\mathrm{C}$ & $\mathrm{C}$ & $\mathrm{C}$ \\
Early Calwonder (ECW) & $\mathrm{C}$ & $\mathrm{C}$ & $\mathrm{C}$ & $\mathrm{C}$ \\
Jupiter & $\mathrm{C}$ & $\mathrm{C}$ & $\mathrm{C}$ & $\mathrm{C}$ \\
King Arthur $(B s 1)$ & $\mathrm{C}$ & $\mathrm{C}$ & $\mathrm{C}$ & $\mathrm{C}$ \\
ECW-10R $(B s 1)$ & $\mathrm{C}$ & $\mathrm{C}$ & $\mathrm{C}$ & $\mathrm{C}$ \\
Boyton Bell $(B s 1, B s 2)$ & $\mathrm{HR}$ & $\mathrm{HR}$ & $\mathrm{C}$ & $\mathrm{C}$ \\
X3R Camelot $(B s 2)$ & $\mathrm{HR}$ & $\mathrm{HR}$ & $\mathrm{C}$ & $\mathrm{C}$ \\
Commandant $(B s 2)$ & $\mathrm{HR}$ & $\mathrm{HR}$ & $\mathrm{C}$ & $\mathrm{C}$ \\
Sentinel $(B s 1, B s 3)$ & $\mathrm{HR}$ & $\mathrm{C}$ & $\mathrm{HR}$ & $\mathrm{C}$ \\
\hline
\end{tabular}

${ }^{y}$ Functional avirulence gene or genes in parenthesis; $\mathrm{C}=$ compatible; HR = incompatible, hypersensitive response.

${ }^{\mathrm{z}}$ Resistance gene or genes in parenthesis.
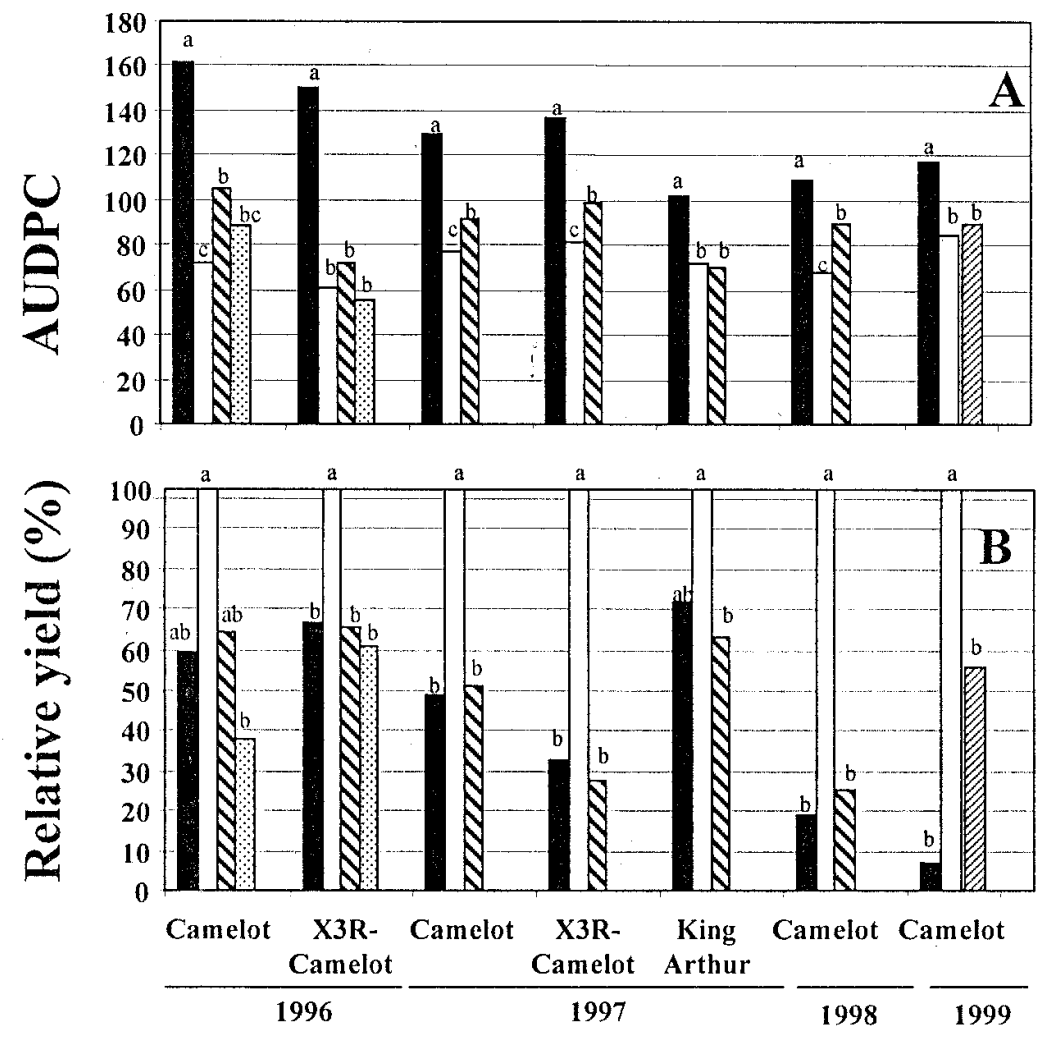

\footnotetext{
Control SABM $17 \mathrm{~g}$ ai/ha, 7 days $\square$ Copper+maneb, 7 days $\mathrm{ABM} 35 \mathrm{~g}$ ai/ha, 7 days
}

Fig. 1. Bacterial spot severity, as area under disease progress curves (AUDPC), and the yield on several bell pepper cultivars inoculated with compatible races of Xanthomonas axonopodis pv. vesicatoria and treated with acibenzolar-S-methyl (ABM) at 17 or $35 \mathrm{~g}$ a.i./ha, and their controls, 1996 to 1999. A, AUDPC; B, yields, relative to the standard copper hydroxide (1.72 kg a.i./ha) plus maneb (1.26 kg a.i./ha) $(=100 \%)$. For each cultivar and date, bars with the same letter are not significantly different $(P<$ 0.05 , least-squares means option of the general linear models procedure of SAS).

growth. Plots consisted of single plant rows, with 9 to 17 plants per row. Bacterial spot-free (noninoculated) plots consisted of three rows with nine plants each. The rows were $112 \mathrm{~cm}$ apart with plants spaced 35 $\mathrm{cm}$ apart. Treatments were arranged in a randomized complete block with four replications.

In 1996, the cultivars Camelot and X3R Camelot were used (Table 1). Two weeks after transplanting, inoculated plants were placed in the center of each row. Each of these plants had been inoculated with two strains each of races 1,3 , and 4 (Table 1) by immersing them in a suspension containing an equal concentration of each strain $\left(10^{6} \mathrm{CFU} / \mathrm{ml}\right)$. Camelot is susceptible to all these races, whereas X3R Camelot is susceptible to the strains of race 4 (Table 1). In 1997, Camelot, X3R Camelot, and King Arthur were used (Table 1). One week after transplanting, a plant in the center of each plot was inoculated by carefully bending the upper portion of the plant and immersing it in a suspension (approximately $10^{7} \mathrm{CFU} / \mathrm{ml}$ ) containing two race 6 strains and $0.04 \%$ Silwet L-77. All of the cultivars used were susceptible to race 6 strains (Table 1). In 1998, two experiments were conducted using Camelot. In the first (1998-I), inoculations were performed using the same methods and strains as in 1997. In the second experiment (1998-II), Camelot plants were not inoculated and remained bacterial spotfree. In the 1999 plots, Camelot was used. One week after transplanting, the central plant of each row was inoculated by immersion in an inoculum suspension containing three strains of race 3 , as described previously (1999-I). Six pepper genotypes also were planted in noninoculated plots (1999-II): Camelot, X3R-Camelot, King Arthur, Sentinel, Boynton Bell, and Commandant.

Plants in inoculated plots were either (i) nonsprayed, (ii) sprayed weekly with the grower standard treatment of copper hydroxide (Kocide DF 61.4\%) at $1.72 \mathrm{~kg}$ ai/ha tank mixed with maneb (Maneb 75 DF) at $1.26 \mathrm{~kg}$ ai/ha, or (iii) sprayed weekly or every 2 weeks with ABM alone (17 or $35 \mathrm{~g}$ ai/ha or both) or in combination (17 $\mathrm{g}$ ai/ha) with copper hydroxide $(1.72 \mathrm{~g}$ ai/ha) for a total of five to eight applications (Fig. 1, Tables 2 and 3). Noninoculated plots (1998-II and 1999-II) were not sprayed or sprayed every 2 weeks with $\mathrm{ABM}$ at 17 or $35 \mathrm{~g}$ a.i./ha for a total of four applications (Tables 4, 5, and 6). Chemicals were applied using a $\mathrm{CO}_{2}$ sprayer calibrated to deliver 953 liters/ha at $2,800 \mathrm{~g} / \mathrm{cm}^{2}$ (40 psi) (1996, 1998-I, and 1999) or using a highboy calibrated to deliver 607 liters $/ \mathrm{ha}$ at $3,500 \mathrm{~g} / \mathrm{cm}^{2}$ (50 psi) (1997 and 1998-II). Sprays were applied using three flat fan nozzles per row, one over the top center of the row and twodrop nozzles $(30 \mathrm{~cm})$ on each side of the row. 
Disease severity ratings were taken on all plants using a 0-to-9 scale, in which $0=$ no diseased leaves observed, $1=<1 \%$ leaf area diseased, $2=1$ to $10 \%$ leaf area diseased, $3=11$ to $20 \%$ leaf area diseased or defoliated, $4=21$ to $35 \%$ leaf area diseased or defoliated, $5=36$ to $50 \%$ leaf area diseased or defoliated, $6=51$ to $65 \%$ leaf area diseased or defoliated, $7=66$ to $80 \%$ leaf area diseased or defoliated, $8=81$ to $99 \%$ leaf area diseased and very few leaves (one to three) remaining on plant; and $9=$ complete defoliation and plant dying or dead (11). AUDPC was calculated for each treatment (3).

The number of visible flower buds was counted on four plants per plot 4 and 5 weeks after transplanting in the noninoculated 1999-II experiment. On the second evaluation date, the number of open flowers also was recorded. Vegetative shoot apices (emerging new branches) were counted on four plants per plot on Camelot and King Arthur 8 weeks after transplanting. Fruit were harvested from all plots (inoculated or not inoculated) three times in 1996, twice in 1997, and four times in 1998 and 1999. For each year, yields from combined harvests are presented. In 1998-II and 1999-II, the center row of the plots was harvested when the fruit was mature green. Remaining rows in each plot were harvested when majority of the fruit in the unsprayed plots were red. In 1998-II, all fruit were harvested; whereas, in 1999-II, only the red fruit were picked. In both years, the number of fruit per plot was counted, and the mean weight per fruit was calculated.

Data analysis. Number of fruit, flower buds, opened flowers, and apical tips were transformed (square root of $[\mathrm{x}+0.5]$ ) before further analysis, to normalize the data
(31). Treatment effects were evaluated by using the general linear models (GLM) procedure of SAS (version 7; SAS Institute Inc., Cary, NC). Means were separated with least squares estimates of marginal means (LSMEANS statement).

\section{RESULTS}

Greenhouse experiments. The effect of induced resistance was evident on challenges done as early as 3 days after ABM treatment. At that time, the severity of bacterial spot on ECW-10R, Camelot, X3R Camelot, and Jupiter plants sprayed with $\mathrm{ABM}$ was significantly less than on nonsprayed controls (Fig. 2). Only ECW-10R expressed resistance after 30 days of treatment. No cultivar exhibited resistance after 40 days (Fig. 2).

Field experiments. Seven or more applications of $\mathrm{ABM}$ at 17 or $35 \mathrm{~g}$ ai/ha

Table 2. Bacterial spot severity expressed as area under the disease progress curves for several bell pepper cultivars inoculated with compatible races of Xanthomonas axonopodis pv. vesicatoria and treated with different combinations of acibenzolar-S-methyl (ABM, $17 \mathrm{~g}$ a.i./ha) plus copper hydroxide (1.72 $\mathrm{kg}$ a.i./ha), 1996-99

\begin{tabular}{|c|c|c|c|c|c|c|c|c|c|c|c|}
\hline \multirow[b]{2}{*}{ Year, pepper genotype } & \multicolumn{11}{|c|}{ Chemical treatment $^{\mathrm{z}}$} \\
\hline & 1 & 2 & 3 & 4 & 5 & 6 & 7 & 8 & 9 & 10 & 11 \\
\hline \multicolumn{12}{|l|}{1996} \\
\hline Camelot & $162 \mathrm{a}$ & $72 \mathrm{~b}$ & $70 \mathrm{~b}$ & $\ldots$ & $\ldots$ & $\ldots$ & $\ldots$ & $\cdots$ & $\cdots$ & $\cdots$ & $\cdots$ \\
\hline X3R-Camelot & $150 \mathrm{a}$ & $61 \mathrm{~b}$ & $55 \mathrm{~b}$ & $\ldots$ & $\cdots$ & $\cdots$ & $\cdots$ & $\cdots$ & $\cdots$ & $\cdots$ & $\cdots$ \\
\hline \multicolumn{12}{|l|}{1997} \\
\hline Camelot & $130 \mathrm{a}$ & $77 \mathrm{c}$ & $\ldots$ & $92 \mathrm{~b}$ & $96 \mathrm{~b}$ & $96 \mathrm{~b}$ & $\ldots$ & $\ldots$ & $\ldots$ & $\ldots$ & $\ldots$ \\
\hline X3R-Camelot & $137 \mathrm{a}$ & $81 \mathrm{c}$ & $\ldots$ & $91 \mathrm{~b}$ & $91 \mathrm{~b}$ & $96 \mathrm{~b}$ & $\ldots$ & $\ldots$ & $\ldots$ & $\ldots$ & $\ldots$ \\
\hline King Arthur & $102 \mathrm{a}$ & $72 \mathrm{~b}$ & $\ldots$ & $73 \mathrm{~b}$ & $73 \mathrm{~b}$ & $76 \mathrm{~b}$ & $\ldots$ & $\ldots$ & $\ldots$ & $\ldots$ & $\ldots$ \\
\hline \\
\hline $\begin{array}{l}\text { Camelot } \\
1999\end{array}$ & $109 \mathrm{a}$ & $68 \mathrm{~b}$ & $61 \mathrm{~b}$ & $\cdots$ & $\cdots$ & $\cdots$ & $69 \mathrm{~b}$ & $63 \mathrm{~b}$ & $\cdots$ & $\cdots$ & $\cdots$ \\
\hline Camelot & $118 \mathrm{a}$ & $84 \mathrm{~b}$ & $84 \mathrm{~b}$ & $\ldots$ & $\ldots$ & $\ldots$ & $\ldots$ & $\ldots$ & $92 \mathrm{~b}$ & $91 \mathrm{~b}$ & $71 \mathrm{c}$ \\
\hline
\end{tabular}

Table 3. Yield, expressed as a percent of the standard treatment copper hydroxide (1.72 kg a.i./ha) plus maneb (1.26 g a.i./ha) of several bell pepper cultivars inoculated with compatible races of Xanthomonas axonopodis pv. vesicatoria and treated with different combinations of acibenzolar-S-methyl (ABM, $17 \mathrm{~g}$ a.i./ha) plus copper hydroxide, 1996-99

\begin{tabular}{|c|c|c|c|c|c|c|c|c|c|c|c|}
\hline \multirow[b]{2}{*}{ Year, pepper genotype } & \multicolumn{11}{|c|}{ Chemical treatment ${ }^{\mathrm{z}}$} \\
\hline & 1 & 2 & 3 & 4 & 5 & 6 & 7 & 8 & 9 & 10 & 11 \\
\hline \multicolumn{12}{|l|}{1996} \\
\hline Camelot & $59 \mathrm{a}$ & $100 \mathrm{a}$ & $67 \mathrm{a}$ & $\ldots$ & $\ldots$ & $\ldots$ & $\ldots$ & $\ldots$ & $\ldots$ & $\ldots$ & $\ldots$ \\
\hline X3R-Camelot & $67 \mathrm{~b}$ & $100 \mathrm{a}$ & $74 \mathrm{ab}$ & $\ldots$ & $\ldots$ & $\ldots$ & $\ldots$ & $\ldots$ & $\ldots$ & $\ldots$ & $\ldots$ \\
\hline \multicolumn{12}{|l|}{1997} \\
\hline Camelot & $49 \mathrm{~b}$ & $100 \mathrm{a}$ & $\ldots$ & $99 \mathrm{a}$ & $77 \mathrm{ab}$ & $75 \mathrm{ab}$ & $\ldots$ & $\ldots$ & $\ldots$ & $\ldots$ & $\ldots$ \\
\hline X3R-Camelot & $33 \mathrm{c}$ & $100 \mathrm{a}$ & $\ldots$ & $58 \mathrm{bc}$ & $64 \mathrm{~b}$ & $56 \mathrm{bc}$ & $\ldots$ & $\ldots$ & $\ldots$ & $\ldots$ & $\ldots$ \\
\hline King Arthur & $72 \mathrm{a}$ & $100 \mathrm{a}$ & $\ldots$ & $95 \mathrm{a}$ & $94 \mathrm{a}$ & $100 \mathrm{a}$ & $\ldots$ & $\ldots$ & $\ldots$ & $\ldots$ & $\ldots$ \\
\hline \multicolumn{12}{|l|}{1998} \\
\hline Camelot & $19 \mathrm{c}$ & $100 \mathrm{a}$ & $68 \mathrm{ab}$ & $\ldots$ & $\ldots$ & $\ldots$ & $60 \mathrm{~b}$ & $70 a b$ & $\ldots$ & $\ldots$ & $\ldots$ \\
\hline \multicolumn{12}{|l|}{1999} \\
\hline Camelot & $7 \mathrm{c}$ & $100 \mathrm{a}$ & $56 \mathrm{ab}$ & $\ldots$ & $\ldots$ & $\ldots$ & $\ldots$ & $\ldots$ & $39 \mathrm{bc}$ & $66 a b$ & $68 \mathrm{ab}$ \\
\hline
\end{tabular}

$\mathrm{z}$ Treatments: 1 = nontreated control; $2=$ copper + maneb applied weekly; $3=\mathrm{ABM}+$ copper applied weekly; $4=\mathrm{ABM}$ first to fourth application, copper first and second, copper + maneb fifth to seventh application; 5 = ABM first to fourth application, copper first and second, copper + maneb fifth and seventh application; $6=\mathrm{ABM}$ first to fourth application, copper first and second application; $7=\mathrm{ABM}$ first, third, fifth, and seventh application, copper first to seventh application; $8=\mathrm{ABM}$ first to third application, copper first to seventh application; $9=$ copper + maneb first to fifth application, ABM sixth and eighth application; $10=$ copper + maneb first to fifth application, ABM + copper sixth and eighth application; $11=$ copper first to seventh application, ABM + copper first, third, fifth, and seventh application. For each cultivar and date, means followed by the letter are not significantly different $(P<0.05$, least-squares means option of the general linear models procedure of SAS). 
caused a significant reduction in bacterial spot when compared to nontreated controls (Fig. 1A). Yields were much less than for copper-plus-maneb-treated plots, and similar to nontreated plots (Fig. 1B). Certain combinations of $\mathrm{ABM}$ at $17 \mathrm{~g}$ ai/ha applied with or alternated with copper reduced the severity of disease (Table 2) and resulted in yields similar to the plants treated weekly with copper plus maneb (Table 3). With King Arthur, all combinations of ABM plus copper controlled disease similarly and had yields similar to those for the plants treated weekly with copper plus maneb (Tables 2 and 3). Yields in some combination treatments were re- duced compared to the standard copper plus maneb, although not significantly (Table 3). However, yields in these treatments were significantly greater than in nontreated plots.

Four weeks after transplanting in the disease-free 1999-II experiment, there was no difference in the number of flower buds on plants sprayed twice or not sprayed with ABM (Table 4). Five weeks after transplanting, ABM-sprayed Admiral and Boyton Bell had fewer flower buds ( $P=$ 0.001 and 0.042 , respectively) and King Arthur and X3R Camelot had fewer opened flowers $(P=0.032$ and 0.037 , respectively) than nonsprayed plants (Table
4). Considering buds and opened flowers together, Admiral and King Arthur sprayed with ABM had fewer opened flowers and flower buds than nonsprayed controls $(P=$ 0.001 and 0.048 , respectively). There was no difference in the number of new branches of plants treated or not treated with ABM. Eight weeks after transplanting, Camelot and King Arthur plants had a mean of 33 and 41 new branches emerging when they were treated with $\mathrm{ABM}$ and 36 and 41 when they were not treated, respectively $(P>0.05)$.

In the noninoculated 1998-II experiment, the yield of Camelot was not affected by ABM treatments (Tables 5 and

Table 4. Number of flower buds and opened flowers on different bacterial spot-free bell pepper cultivars treated or not treated with acibenzolar-S-methyl (ABM, $17 \mathrm{~g}$ a.i./ha) every 2 weeks ${ }^{\mathrm{z}}$

\begin{tabular}{|c|c|c|c|c|c|c|c|c|}
\hline \multirow[b]{2}{*}{ Cultivars } & \multicolumn{2}{|c|}{ Flower buds 4 WAT } & \multicolumn{2}{|c|}{ Flower buds 5 WAT } & \multicolumn{2}{|c|}{ Opened flowers 5 WAT } & \multicolumn{2}{|c|}{ Flower buds + opened flowers, 5 WAT } \\
\hline & ABM-treated & Nontreated & ABM-treated & Nontreated & ABM-treated & Nontreated & ABM-treated & Nontreated \\
\hline Admiral & $11.9 \mathrm{a}$ & $13.6 \mathrm{a}$ & $30.4 \mathrm{~b}$ & $40.5 \mathrm{a}$ & $0.5 \mathrm{a}$ & $1.1 \mathrm{a}$ & $30.9 \mathrm{~b}$ & $41.6 \mathrm{a}$ \\
\hline Commandant & $9.2 \mathrm{a}$ & $11.0 \mathrm{a}$ & $26.6 \mathrm{a}$ & $31.6 \mathrm{a}$ & $0.4 \mathrm{a}$ & $1.0 \mathrm{a}$ & $27.0 \mathrm{a}$ & $32.6 \mathrm{a}$ \\
\hline Boyton Bell & $14.6 \mathrm{a}$ & $14.4 \mathrm{a}$ & $35.3 \mathrm{~b}$ & $41.9 \mathrm{a}$ & $1.8 \mathrm{a}$ & $1.8 \mathrm{a}$ & $37.0 \mathrm{a}$ & $43.6 \mathrm{a}$ \\
\hline Camelot & $10.0 \mathrm{a}$ & $10.6 \mathrm{a}$ & $24.1 \mathrm{a}$ & $24.1 \mathrm{a}$ & $0.3 \mathrm{a}$ & $0.4 \mathrm{a}$ & $24.4 \mathrm{a}$ & $24.5 \mathrm{a}$ \\
\hline X3R Camelot & $12.0 \mathrm{a}$ & $12.6 \mathrm{a}$ & $27.6 \mathrm{a}$ & $30.9 \mathrm{a}$ & $1.1 \mathrm{~b}$ & $2.3 \mathrm{a}$ & $28.8 \mathrm{a}$ & $33.3 \mathrm{a}$ \\
\hline King Arthur & $9.5 \mathrm{a}$ & $9.5 \mathrm{a}$ & $32.6 \mathrm{a}$ & $38.0 \mathrm{a}$ & $0.3 \mathrm{~b}$ & $1.3 \mathrm{a}$ & $32.9 \mathrm{~b}$ & $39.3 \mathrm{a}$ \\
\hline
\end{tabular}

${ }^{z}$ Counts were done 4 and 5 weeks after transplanting (WAT) at Sandhills Research Station, North Carolina, 1999. All data were transformed to sqrt (X + $0.5)$ before analysis. Means of nontransformed data are presented for clarity. Means separation was performed with the least-squares means option of the general linear models procedure of SAS. For each pepper cultivar and variable evaluated, means followed by the same letters are not significantly different $(P=0.05)$.

Table 5. Yield components of different bacterial spot-free bell pepper cultivars treated with acibenzolar-S-methyl (ABM) at 17 or $35 \mathrm{~g}$ a.i./ha or not treated (NT) every 2 weeks $^{y}$

\begin{tabular}{|c|c|c|c|c|c|c|c|c|c|c|}
\hline \multirow[b]{2}{*}{ Cultivars } & \multicolumn{3}{|c|}{ Number of fruit/plant ${ }^{\mathrm{z}}$} & \multicolumn{3}{|c|}{ Fruit weight (g) } & \multicolumn{3}{|c|}{ Yield/plant (g) } & \multirow[b]{2}{*}{ Yield (\% of NT) } \\
\hline & $35 \mathrm{~g}$ a.i./ha & 17 g a.i./ha & NT & $35 \mathrm{~g}$ a.i./ha & $17 \mathrm{~g}$ a.i./ha & NT & $35 \mathrm{~g}$ a.i./ha & $17 \mathrm{~g}$ a.i./ha & NT & \\
\hline \multicolumn{11}{|l|}{ 1998-II } \\
\hline Camelot & $7.2 \mathrm{a}$ & $6.6 \mathrm{a}$ & $6.2 \mathrm{a}$ & $93.7 \mathrm{~b}$ & $98.5 \mathrm{ab}$ & $108.2 \mathrm{a}$ & $670 \mathrm{a}$ & $650 \mathrm{a}$ & $670 \mathrm{a}$ & $100 / 97$ \\
\hline \multicolumn{11}{|l|}{ 1999-II } \\
\hline Camelot & $\ldots$ & $10.6 \mathrm{a}$ & $10.3 \mathrm{a}$ & $\ldots$ & $134.1 \mathrm{a}$ & $145.3 \mathrm{a}$ & $\ldots$ & $1,370 \mathrm{a}$ & $1,490 \mathrm{a}$ & 92 \\
\hline X3R Camelot & $\ldots$ & $9.0 \mathrm{a}$ & $10.3 \mathrm{a}$ & $\ldots$ & $131.0 \mathrm{a}$ & $134.9 \mathrm{a}$ & $\ldots$ & $1,180 \mathrm{a}$ & $1,340 \mathrm{a}$ & 88 \\
\hline Commandant & $\ldots$ & $11.3 \mathrm{a}$ & $11.6 \mathrm{a}$ & $\ldots$ & $146.5 \mathrm{a}$ & $159.1 \mathrm{a}$ & $\ldots$ & $1,640 \mathrm{a}$ & $1,800 \mathrm{a}$ & 91 \\
\hline Admiral & $\ldots$ & $9.4 \mathrm{a}$ & $11.1 \mathrm{a}$ & $\ldots$ & $144.7 \mathrm{a}$ & $153.4 \mathrm{a}$ & $\ldots$ & $1,350 \mathrm{~b}$ & $1,680 \mathrm{a}$ & 80 \\
\hline Boynton Bell & $\ldots$ & $11.0 \mathrm{a}$ & $12.9 \mathrm{a}$ & $\ldots$ & $156.0 \mathrm{a}$ & $148.0 \mathrm{a}$ & $\ldots$ & $1,630 \mathrm{a}$ & $1,890 \mathrm{a}$ & 86 \\
\hline King Arthur & $\ldots$ & $9.1 \mathrm{a}$ & $9.7 \mathrm{a}$ & $\ldots$ & $144.5 \mathrm{a}$ & $152.9 \mathrm{a}$ & $\ldots$ & 1,270 a & $1,440 \mathrm{a}$ & 88 \\
\hline
\end{tabular}

y Plants were harvested at the mature-green stage at Sandhills Research Station, North Carolina. Means separation was performed with the least-squares means option of the general linear models procedure of SAS. For each pepper cultivar and variable evaluated, means followed by the same letter are not significantly different $(P=0.05) ; \ldots=$ not evaluated in 1999 .

${ }^{z}$ Number of fruit/plant data $(X)$ were transformed to square root $(X+0.5)$ before analysis. Means of nontransformed data are presented for clarity.

Table 6. Yield components of different bacterial spot-free bell pepper cultivars treated with acibenzolar-S-methyl (ABM) at 17 or $35 \mathrm{~g}$ a.i./ha or not treated (NT) every 2 weeks $^{\mathrm{y}}$

\begin{tabular}{|c|c|c|c|c|c|c|c|c|c|c|}
\hline \multirow[b]{2}{*}{ Cultivars } & \multicolumn{3}{|c|}{ Number of fruit/plant ${ }^{\mathrm{z}}$} & \multicolumn{3}{|c|}{ Fruit weight (g) } & \multicolumn{3}{|c|}{ Yield/plant (g) } & \multirow[b]{2}{*}{ Yield (\% of NT) } \\
\hline & 35 g a.i./ha & $17 \mathrm{~g}$ a.i./ha & NT & 35 g a.i./ha & 17 g a.i./ha & NT & 35 g a.i./ha & 17 g a.i./ha & NT & \\
\hline \multicolumn{11}{|l|}{ 1998-II } \\
\hline Camelot & $9.3 \mathrm{a}$ & $7.3 \mathrm{ab}$ & $6.8 \mathrm{~b}$ & $124 \mathrm{c}$ & $144 \mathrm{~b}$ & $159 \mathrm{a}$ & $1,150 \mathrm{a}$ & $1,050 \mathrm{a}$ & $1,080 \mathrm{a}$ & $106 / 97$ \\
\hline \multicolumn{11}{|l|}{ 1999-II } \\
\hline Camelot & $\ldots$ & $0.5 \mathrm{a}$ & $1.3 \mathrm{a}$ & $\ldots$ & $70.0 \mathrm{a}$ & $210.0 \mathrm{a}$ & $\ldots$ & $140 \mathrm{a}$ & $360 \mathrm{a}$ & 39 \\
\hline X3R Camelot & $\ldots$ & $1.5 \mathrm{a}$ & $4.8 \mathrm{a}$ & $\ldots$ & $140.0 \mathrm{a}$ & $224.0 \mathrm{a}$ & $\ldots$ & $280 \mathrm{a}$ & $1,060 \mathrm{a}$ & 26 \\
\hline Commandant & $\ldots$ & $2.5 \mathrm{a}$ & $4.0 \mathrm{a}$ & $\ldots$ & $321.1 \mathrm{a}$ & $284.5 \mathrm{a}$ & $\begin{array}{l}\cdots \\
\cdots\end{array}$ & $780 \mathrm{a}$ & $1,010 \mathrm{a}$ & 77 \\
\hline Admiral & $\ldots$ & $2.0 \mathrm{a}$ & $3.0 \mathrm{a}$ & $\ldots$ & $115.7 \mathrm{a}$ & $184.7 \mathrm{a}$ & $\ldots$ & $500 \mathrm{a}$ & $780 \mathrm{a}$ & 64 \\
\hline Boynton Bell & $\ldots$ & $4.3 \mathrm{a}$ & $1.0 \mathrm{a}$ & $\ldots$ & $203.0 \mathrm{a}$ & $121.3 \mathrm{a}$ & $\ldots$ & $1,060 \mathrm{a}$ & $250 \mathrm{a}$ & 424 \\
\hline King Arthur & $\begin{array}{l}\cdots \\
\cdots\end{array}$ & $4.0 \mathrm{a}$ & $10.0 \mathrm{a}$ & $\begin{array}{l}\cdots \\
\cdots\end{array}$ & $246.1 \mathrm{a}$ & $225.2 \mathrm{a}$ & $\begin{array}{l}\cdots \\
\cdots\end{array}$ & $980 \mathrm{a}$ & $2,220 \mathrm{a}$ & 44 \\
\hline
\end{tabular}

y Plants were harvested at the red fruit stage at Sandhills Research Station, North Carolina. 1998-II = all fruit harvested, 1999-II $=$ only red fruit harvested Means separation was performed with the least-squares means option of the general linear models procedure of SAS. For each pepper cultivar and variable evaluated, means followed by the same letter are not significantly different $(P=0.05) ; \ldots=$ not evaluated in 1999 .

${ }^{\mathrm{z}}$ Number of fruit/plant data $(X)$ were transformed to square root $(X+0.5)$ before analysis. Means of non-transformed data are presented for clarity. 
6). Although ABM-sprayed plants had more fruit, the fruit were smaller than those of nonsprayed plants, at both the mature green (Table 5) and red harvest (Table 6). In the red fruit harvest, $71 \%$ of the fruit in control plots were red, as compared to 21 and $40 \%$ in plots sprayed with $\mathrm{ABM}$ at 35 and $17 \mathrm{~g}$ ai/ha, respectively. In 1999-II, ABM caused a significant reduction in the yield per plant of Admiral $(P=0.020)$ at the mature green harvest compared to nontreated plots (Table 5). A reduction of fruit weight was detected when yields of all cultivars were pooled $(P=0.0355)$, but not when chemical treatments were compared for each cultivar individually. No yield differences were detected at the red fruit harvest (Table 6).

\section{DISCUSSION}

Bacterial spot, caused by $X$. axonopodis pv. vesicatoria, is an important disease in many bell pepper-growing regions. The presence of copper- and streptomycin-resistant strains complicate chemical control strategies $(14,21,29)$. The public in general is concerned about potential human and environmental hazards of agrochemical use which, in turn, has led to increased regulation of pesticides (13). Another management strategy is the use of one or a few genes for resistance to specific races. However, there is ample evidence of lack of durability of this resistance as rapid race shifts have occurred in the field, leading to a seemingly endless search for new genes. For these reasons, induced resistance has attracted the attention of scientists and chemical companies, and ABM is the first synthetic plant activator of SAR to become available (32).

We have shown $A B M$ to be effective in control of bacterial spot on bell pepper. The SAR response is effective in plants with no known major resistance genes (ECW, Camelot, and Jupiter) as well as in those that have major resistance genes (ECW-10R, X3R Camelot, and King Arthur). Induced resistance in bell pepper is expressed as early as 3 days after treatment and continues for at least 2 weeks. In contrast, ABM-induced resistance in monocots may be considerably longer, lasting the entire growing season in wheat (6). Applications of $\mathrm{ABM}$ in combination with copper resulted in control of bacterial spot similar to that of the standard weekly treatment with a tank mix of copper plus maneb. Effects on yield were cultivar related. In general, yields of ABM-treated plants were significantly greater than in nonsprayed plots but, in most cultivartreatment combinations, less than that in copper plus maneb plots. The negative effect on yields was exacerbated with intensive and prolonged use of ABM by itself (every week, for a total of seven to eight applications) on all bell pepper genotypes tested.
In the absence of bacterial spot, the pattern of growth of ABM-sprayed plants was similar to nonsprayed plants (i.e., there was no difference in the number of new emerging branches). Flowers develop in branch axils of pepper plants; therefore, the potential for ABM-sprayed plants to develop flowers and fruit was the same as for nonsprayed plants. However, the sum of the number of opened flowers and flower buds counted 5 weeks after transplanting was 0.5 to $26 \%$ less for ABM-sprayed plants than for nonsprayed controls, depending on cultivar. This could mean that some flower buds did not develop or aborted before counting. The reduction in the number of flower buds could be responsible for the lower yield of Admiral at the green fruit harvest, because yield losses were mainly attributable to a reduction in the number of mature fruits at harvest. Another possible contributing factor to the yield reduction could be a delay in fruit maturity observed in all experiments each year. For example, in 1998-II, when all fruit were picked at the red fruit harvest, plots treated with ABM had a significantly lower proportion of red fruit compared with nontreated plots harvested at the same time. Inoculated plants, not sprayed or sprayed with copper plus maneb, were associated with the highest yields in either
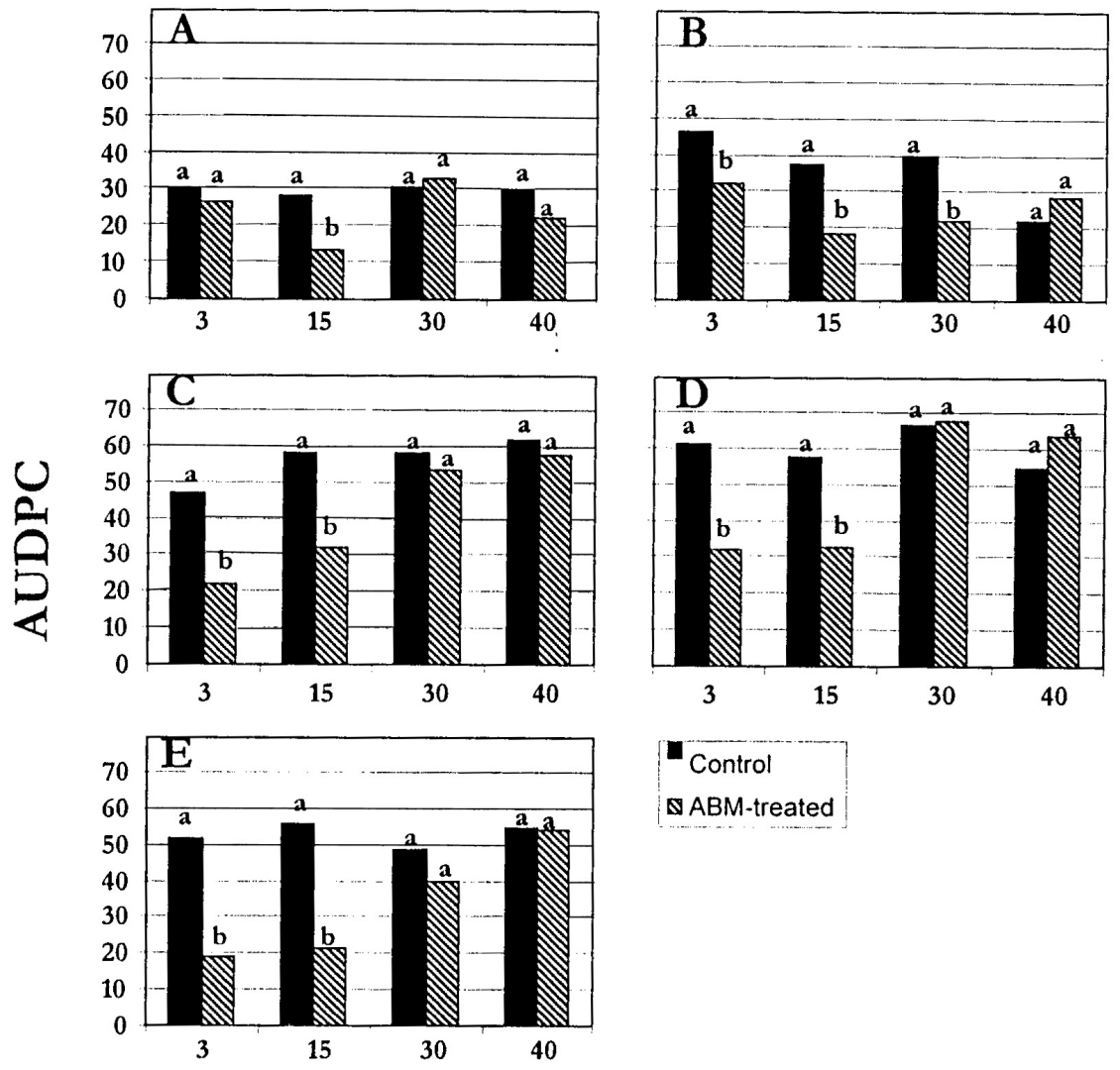

N $A B M$-treated the first or second harvest. Plants sprayed with ABM alone or combined with copper hydroxide, in contrast, had the greatest yields in either the second or third harvest, again suggesting a delay in fruit maturity or fruit set. In contrast, yields of chili peppers are not affected by ABM treatments (32).

Our data support the hypothesis that there could be a cost when induced resistance is expressed constitutively, evidenced as a reduction or delay in fruit set, maturity, or both. In other plant-pest systems, when defense mechanisms were induced in plants, there was an enhanced fitness if parasites were present but a reduced fitness (i.e., less seed production) when parasites were absent, suggesting that induced fitness has an inherent cost (2). So, if defense is expensive to plants in terms of energy or precursors, conversion of resistance that is inducible to constitutive may result in reduced yields (7). In some cases, these costs may be overcome by agricultural practices such as fertilization and irrigation (1). As an example, a slight chlorosis in ABMtreated tobacco plants was corrected by an application of calcium nitrate (4). A problem in allocation of plant resources might be aggravated if plant activators are used under conditions of crop stress. In our experiments, yields were not affected in 
ABM-treated plots in which plants grew optimally from transplanting through harvest, as in the 1998-II experiments. These plants also were bacterial spot-free. Weed infestations were a problem early in the 1998-I experiments and bacterial spot was moderate to severe. In this case, the yields were reduced when compared to the copper plus maneb plots. After four consecutive days of maximum temperatures greater than $36^{\circ} \mathrm{C}$ in 1999 , leaves of all plants developed a crinkled appearance and a light green color. This condition was exacerbated on plants treated with ABM.

In summary, it seemed that the continued application of ABM may have a horticultural cost manifested as a loss in fruit yield in bell pepper; this was most evident when ABM was applied weekly. Some combinations of ABM plus copper were promising, but results varied with plant genotypes. It is possible that a continuous expression of resistance increases the sensitivity to stresses, and the response of cultivars could be related to an inherent ability to respond to those stresses. Environment and cultivar genotype can influence the effect of AMB on yield of bell pepper; therefore, the standard treatment of copper plus maneb currently remains the best spray program.

\section{ACKNOWLEDGMENTS}

We thank T. Abernethy, D. W. Pollard, and the staff at the NCARS Sandhills Research Station for their assistance with portions of this project.

\section{LITERATURE CITED}

1. Agrawal, A. A. 1999. Induced plant defense: evolution on induction and adaptive phenotypic plasticity. Pages 251-268 in: Induced Plant Defenses Against Pathogens and Herbivores. Biochemistry, Ecology, and Agriculture. A. A. Agrawal, S. Tuzun, and E. Bent, eds. APS Press, St. Paul, MN.

2. Baldwin, I. T. 1998. Jasmonate-induced responses are costly but benefit plants under attack in native populations. Proc. Natl. Acad. Sci. 95:8113-8118.

3. Campbell, C. L., and Madden, L. V. 1990. Introduction to Plant Disease Epidemiology. John Wiley \& Sons, Inc., New York.

4. Cole, D. L. 1999. The efficacy of acibenzolar$S$-methyl, an inducer of systemic acquired resistance, against bacterial and fungal diseases of tobacco. Crop Prot. 18:267-273.

5. Friedrich, L., Lawton, K., Ruess, W., Masner, P., Specker, N., Gut Rella, M., Meier, B., Dincher, S., Staub, T., Uknes, S., Métraux, J.P., Kessmann, H., and Ryals, J. 1996. A benzothiadiazole derivative induces systemic acquired resistance in tobacco. Plant J. 10:6170.

6. Görlach, J., Volrath, S., Knauf-Beiter, G., Hengy, G., Beckhove, U., Kogel, K.-H., Oostendorp, M., Staub, T., Ward, E., Kessmann, H., and Ryals, J. 1996. Ben- zothiadiazole, a novel class of inducers of systemic acquired resistance, activates gene expression and disease resistance in wheat. Plant Cell 8:629-643.

7. Karban, R., and Kuc, J. 1999. Induced resistance against pathogens and herbivores: An overview. Pages 1-18 in: Induced Plant Defenses Against Pathogens and Herbivores. Biochemistry, Ecology, and Agriculture. A. A Agrawal, S. Tuzun, and E. Bent, eds. APS Press, St. Paul, MN.

8. Kessmann, H., Stauv, T., Hofmann, C., Maetzke, T., and Herzog, J. 1994. Induction of systemic acquired disease resistance in plants by chemicals. Annu. Rev. Phytopathol. 32:439-459.

9. Kousik, C. S., and Ritchie, D. F. 1996. Race shift in Xanthomonas campestris pv. vesicatoria within a season in field-grown pepper. Phytopathology 86:952-958.

10. Kousik, C. S., and Ritchie, D. F. 1996. Disease potential of pepper bacterial spot pathogen races that overcome the $B s 2$ gene for resistance. Phytopathology 86:1336-1343.

11. Kousik, C. S., Sanders, D. C., and Ritchie, D. F. 1996. Mixed genotypes combined with copper sprays to manage bacterial spot of bell peppers. Phytopathology 86:502-508.

12. Lawton, K., Friedrich, L., Hunt, M., Weymann, K., Delaney, T., Kessmann, H., Staub, T., and Ryals, J. 1996. Benzothiadiazole induces disease resistance in Arabidopsis by activation of the systemic acquired resistance signal transduction pathway. Plant J. 10:71-82.

13. Lyon, G. D., and Newton, A. C. 1999. Implementation of elicitor-mediated induced resistance in agriculture. Pages 299-318 in: Induced Plant Defenses Against Pathogens and Herbivores. Biochemistry, Ecology, and Agriculture. A. A. Agrawal, S. Tuzun, and E. Bent, eds. APS Press, St. Paul, MN

14. Marco, G. M., and Stall, R. E. 1983. Control of bacterial spot of pepper initiated by strains of Xanthomonas campestris pv. vesicatoria that differ in sensitivity to copper. Plant Dis. 67:779-781.

15. Métraux, J. P., Goy, P. A., Staub, T., Speich, J., Steinemann, A., Ryals, J., and Ward, E. 1991. Induced systemic resistance in cucumber in response to 2,6-dichloroisonicotinic acid and pathogens. Adv. Mol. Genet. Plant-Microbe Interact. 1:432-439.

16. Minsavage, G. V., Dahlbeck, D., Whalen, M. C., Kearney, B., Bonas, U., Staskawicz, B. J., and Stall, R. E. 1990. Gene-for-gene relationships specifying disease resistance in Xanthomonas campestris pv. vesicatoria-pepper interactions. Mol. Plant-Microbe Interact. 3:41-47.

17. Morris, S. W., Vernooij, B., Titatarn, S., Starrett, M., Thomas, S., Wiltse, C. C., Frederiksen, R. A., Bhandhufalck, A., Hulbert, S., and Uknes, S. 1998. Induced resistance responses in maize. Mol. Plant-Microbe Interact. 11:643-658.

18. Ortega, F., Steiner, U., and Dehne, H. W. 1998. Induced resistance: a tool for fungicide resistance management. Pestic. Sci. 53:193196.

19. Pernezny, K., Collins. J., Stall, R. E., Shuler, K., and Datnoff, L. E. 1999. A serious outbreak of race 6 of Xanthomonas campestris pv. vesicatoria on pepper in Southern Florida. Plant Dis. 93:79.

20. Ray, M. J. 1901. Les maladies cryptogamiques des végétaux. Rev. Gén. Bot. XII:145-151.

21. Ritchie, D. F., and Dittapongpitch, V. 1991. Copper- and streptomycin-resistant strains and host differentiated races of Xanthomonas campestris pv. vesicatoria in North Carolina. Plant Dis. 75:733-736.

22. Ritchie, D. F., Kousik, C. S., and Paxton, T. C. 1998. Response of bacterial spot pathogen strains to four major resistance genes in pepper. Page 14 in: Proc. Natl. Pepper Conf. B. Villalon and L. Brandenberger, eds. Citrus Veg. Mag. Tampa, FL.

23. Romero, A. M., Kousik, C. S., and Ritchie, D. F. 1998. Systemic acquired resistance reduces race changes to major resistance genes in pepper. (Abstr.) Phytopathology: 88:S76.

24. Ross, A. F. 1961. Systemic acquired resistance induced by localized virus infections in plants. Virology 14:340-358.

25. Sahin, F., and Miller, S. A. 1998. Resistance in Capsicum pubescens to Xanthomonas campestris pv. vesicatoria pepper race 6. Plant Dis. 82:794-799.

26. Siegrist, J., Glenewinkel, D., Kolle, C., and Schmidtke, M. 1997. Chemically induced resistance in green bean against bacterial and fungal pathogens. J. Plant Dis. Prot. 104:599610.

27. Stall, R. E. 1993. Xanthomonas campestris pv. vesicatoria: cause of bacterial spot of tomato and pepper. Pages 57-60 in: Xanthomonas. J. G. Swings and E. L. Civerolo, eds. Chapman and Hall, London.

28. Stall, R. E., Beaulieu, C., Egel, D., Hodge, N. C., Leite, R. P., Minsavage, G. V., Bouzar, H., Jones, J. B., Alvarez, A. M., and Benedict, A. A. 1994. Two genetically diverse groups of strains are included in Xanthomonas campestris pv. vesicatoria. Int. J. Syst. Bacteriol. 44:47-53.

29. Stall, R. E., Loschke, D. C., and Jones, J. B. 1986. Linkage of copper resistance and avirulence loci on a self-transmissible plasmid in Xanthomonas campestris pv. vesicatoria. Phytopathology 76:240-243.

30. Stall, R. E., and Thayer, P. L. 1962. Streptomycin resistance of the bacterial spot pathogen and control with streptomycin. Plant Dis. Rep. 46:389-392.

31. Steel, R. G. D., Torrie, J. H., and Dickey, D. A., 1997. Principles and Procedures of Statistics: A Biometrical Approach. 3rd ed. McGraw-Hill Book Co., New York.

32. Tally, A., Oostendorp, M., Lawton, K., Staub, T., and Bassi, B. 1999. Commercial development of elicitors of induced resistance to pathogens. Pages 357-370 in: Induced Plant Defenses Against Pathogens and Herbivores. Biochemistry, Ecology, and Agriculture. A. A. Agrawal, S. Tuzun, and E. Bent, eds. APS Press, St. Paul, MN.

33. Uknes, S., Mauch-Mani, B., Moyer, M., Potter, S., Williams, S., Dincher, S., Chandler, D., Slusarenko, A., Ward, E., and Ryals, J. 1992. Acquired resistance in Arabidopsis. Plant Cell 4:645-656.

34. Vauterin, L., Hoste, B., Kersters, K., and Swings, J. 1995. Reclassification of Xanthomonas. Int. J. Syst. Bacteriol. 45:472-489. 